\title{
CalScope: Monitoring SARS-CoV-2 Seroprevalence from Vaccination and Prior Infection in Adults and Children in California May 2021- July 2021
}

Authors: Megha L. Mehrotra, PhD, MPH${ }^{1}$, Esther Lim, MPH ${ }^{1}$, Katherine Lamba, MPH ${ }^{1}$, Amanda Kamali, MD ${ }^{1}$, Kristina W. Lai, MPH ${ }^{1}$, Erika Meza, MPH${ }^{1}$, Irvin Szeto, BS ${ }^{2}$, Peter Robinson, $\mathrm{PhD}^{3}$, Cheng-ting Tsai, $\mathrm{PhD}^{3}$, David Gebhart, BS ${ }^{3}$, Noemi Fonseca, $\mathrm{BS}^{3}$, Andrew $\mathrm{B}$. Martin, $\mathrm{PhD}^{2}$, Catherine Ley, $\mathrm{PhD}^{2}$, Steve Scherf, $\mathrm{BS}^{4}$, James Watt, MD, MPH${ }^{1}$, David Seftel, $\mathrm{MD}, \mathrm{MBA}^{3}$, Julie Parsonnet, $\mathrm{MD}^{2}$, Seema Jain, $\mathrm{MD}^{1}$

Affiliations: ${ }^{1}$ California Department of Public Health, Richmond, CA ${ }^{2}$ Stanford University, Palo Alto, CA ${ }^{3}$ Enable Biosciences, South San Francisco, CA ${ }^{4}$ Gauss Surgical, Menlo Park, CA

\section{Corresponding Author:}

Megha L. Mehrotra, PhD, MPH

California Department of Public Health

850 Marina Bay Pkwy, Richmond, CA 94804

Megha.mehrotra@cdph.ca.gov 
medRxiv preprint doi: https://doi.org/10.1101/2021.12.09.21267565; this version posted December 11, 2021. The copyright holder for this preprint (which was not certified by peer review) is the author/funder, who has granted medRxiv a license to display the preprint in perpetuity.

It is made available under a CC-BY-NC-ND 4.0 International license .

\section{Key Points}

Question: What is the prevalence of vaccine and infection derived antibodies against SARSCoV-2 in adults and children in California?

Findings: In this population-based serosurvey that included 11,161 households, as of June $2021,33 \%$ of adults and $57 \%$ of children were seronegative; $18 \%$ of adults and $26 \%$ of children had antibodies from infection alone; $9 \%$ of adults and $5 \%$ of children had antibodies from both infection and vaccination; and $41 \%$ of adults and $13 \%$ of children had antibodies from vaccination alone.

Meaning: Serostatus varied considerably across geographic regions, suggesting that certain areas might be at increased risk for future COVID-19 surges. 


\section{ABSTRACT}

Importance: Understanding how SARS-CoV-2 seroprevalence varies regionally across California is critical to the public health response to the pandemic.

Objective: To estimate how many Californians have antibodies against SARS-CoV-2 from prior infection or vaccination.

Design: Wave 1 of CalScope: a repeated cross-sectional serosurvey of adults and children enrolled between April 20, 2021 and June 16, 2021.

Setting: A population-based random sample of households in seven counties in California (Alameda, El Dorado, Kern, Los Angeles, Monterey, San Diego, and Shasta) were invited to complete an at-home SARS-CoV-2 antibody test and survey instrument.

Participants: Invitations were sent to 200,000 randomly selected households in the seven counties. From each household, 1 adult (18 years and older) and 1 child (aged 6 months to 17 years) could enroll in the study. There were no exclusion criteria.

Main Outcome(s) and Measures: All specimens were tested for antibodies against the nucleocapsid and spike proteins of SARS-CoV-2. The primary outcome was serostatus category, which was determined based on antibody test results and self-reported vaccination status: seronegative, antibodies from infection only, antibodies from infection and vaccination, and antibodies from vaccination alone. We used inverse probability of selection weights and iterative proportional fitting to account for non-response.

Results: 11,161 households enrolled in wave 1 of CalScope, with 7,483 adults and 1,375 children completing antibody testing. As of June 2021, 27\% (95\% CI [23\%, 31\%]) of adults and $30 \%(95 \% \mathrm{CI}[24 \%, 36 \%])$ of children had evidence of prior SARS-CoV-2 infection; $33 \%$ (95\%CI [28\%, 37\%]) of adults and 57\% (95\% CI [48\%, 66\%]) of children were seronegative. Serostatus varied regionally. Californians 65 years or older were most likely to have antibodies from vaccine alone $(59 \%$; $95 \% \mathrm{CI}[48 \%, 69 \%])$ and children between 511 years old were most likely to have antibodies from prior infection alone $(36 \%$; $95 \% \mathrm{CI}$ [21\%, 52\%]).

Conclusions and Relevance: As of June 2021, a third of adults in California and most children under 18 remained seronegative. Seroprevalence varied regionally and by demographic group, suggesting that some regions or populations might remain more vulnerable to subsequent surges than others. 


\section{INTRODUCTION}

By July 2021, the United States had recorded more than 34 million COVID-19 cases and 600,000 deaths, with over 3.7 million cases and 60,000 deaths in California. ${ }^{1}$ Though all adults and children over 12 have been eligible for COVID-19 vaccination since May 2021 in California, vaccine uptake has been uneven; as of July 31,2021, the percent of persons fully vaccinated ranged from $24 \%$ to $79 \%$ across California counties.

The California Department of Public Health (CDPH) monitors COVID-19 burden and forecasts hospitalizations to determine when additional mitigation measures are required to avoid overwhelming the healthcare system. ${ }^{2}$ Both prior SARS-CoV-2 infection and vaccination reduce the risk of symptomatic COVID-19 and hospitalization, although questions remain regarding the relative level and duration of risk reduction..$^{3-5}$ Accurately forecasting future COVID-19 surges requires estimating population immunity from prior infection or vaccination in order to determine how many people remain susceptible to infection. Estimating population immunity using routine surveillance data is challenging. Since COVID-19 may be asymptomatic and persons with mild illness may not seek testing, many infections are not recognized or reported. Recent studies estimated that $70 \%$ of SARS-CoV-2 infections in California were unaccounted for in the CDPH COVID-19 surveillance system by December 2020.6

Population-based serosurveys can estimate immunity from prior infection or vaccination without the limitations inherent in routine surveillance, and several seroprevalence studies have been completed or are currently underway throughout the United States. ${ }^{7-13}$ However, the studies conducted thus far in California have been limited to convenience samples, restricted to narrow geographic regions, or only powered to produce statewide estimates, thereby limiting their utility for informing public health policy regionally in California. $6,14,15$ Thus, CDPH launched a population-based serosurvey (CalScope) to estimate the proportion of housed and non-institutionalized Californians with evidence of immunity against SARS-CoV-2 from prior infection or vaccination.

\section{METHODS}

\section{Study Design}

CalScope is a repeated cross-sectional study using random address-based sampling of households in seven counties in California. The study re-samples households with replacement over three timepoints.

\section{Sampling Strategy}

We used a multistage sampling strategy to allow for region-specific seroprevalence estimates. The sampling approach was guided by principles of causal transportability ${ }^{16}$ to ensure that the final study results could be appropriately and efficiently generalized to the general population (Appendix). We sampled households in seven counties: Alameda, El Dorado, Kern, Los Angeles, Monterey, San Diego, and Shasta. 
We used an address-based sampling frame created by Marketing Systems Group to select a probability sample of households within each county. The frame uses the United States Postal Service Computerized Delivery Sequence File, which covers all residential delivery locations in the United States, with each address geocoded and linked to the 2015 American Community Survey. ${ }^{17}$ We oversampled households from census tracts with higher proportions of Black households to ensure adequate representation. To enroll a total of 10,000 households, we sampled 200,000 households per wave distributed across the seven counties proportional to each county's population with a minimum of 15,000 households sampled per county.

Sampled households could enroll one adult and one child (6 months to 17 years old). To randomize which eligible household members participated, we instructed households to enroll the adult and child with the next upcoming birthday. Wave 1 enrollment was conducted from April 20, 2021 through June 15, 2021.

Survey Instruments

When registering for the study, participants completed a household enumeration form and elected to order at-home antibody test kits. Participants who declined the antibody test could choose to only complete the survey instrument.

The adult survey asked about demographics of all household members, income, occupation, medical history, COVID-19 vaccination and testing history, and behaviors associated with COVID-19 risk-including mask use and social distancing. The child survey asked about the child participant's demographics, medical and COVID-19 disease history, and attendance in school and other social activities. (Appendix)

\section{Antibody Testing}

Participants were mailed at-home antibody test kits with instructions on how to collect a dried blood spot (DBS) specimen and were asked to return their sample to Enable Biosciences within 30 days. Specimens with inadequate volume or collected $>30$ days before receipt by the laboratory were rejected. All valid specimens received by the laboratory by August 1, 2021 were included in this analysis.

Specimens were tested for both anti-spike and anti-nucleocapsid antibodies using Enable's ADAP SARS-CoV-2 total antibody assay. The assay procedures have been described previously (Appendix). ${ }^{18}$ The assay cutoffs were established by testing 100 healthy controls and set at $99.7 \%$ percentile. The cutoffs for spike and nucleocapsid antibodies were $3.00 \Delta \mathrm{Ct}$ and $1.50 \Delta \mathrm{Ct}$ respectively. The assay was previously shown to be $100 \%$ sensitive and $100 \%$ specific in validation studies using DBS samples against the spike protein and nucleocapsid proteins. ${ }^{18}$

\section{Sampling Weights}

We anticipated that households that enrolled in the study and completed antibody tests would differ from those that did not respond. Thus, we constructed sampling weights to generalize our results from the study sample to the target population: the general population of non-institutionalized, housed residents in each of the seven sampled counties $.19,20$ 
Within each county, there were three levels of selection between the final study sample and target population (Figure 1). The sampled population was all households that were mailed invitations to participate in CalScope; the registered population included all participants that registered for the study and completed a survey instrument; and the final study sample included all registered participants who completed an antibody test. We estimated weights to generalize across each selection step: Step 1) from the final study sample to the registered population, Step 2) from the registered population to the sampled population, and Step 3) from the sampled population to the target population.

We constructed selection diagrams to guide variable selection for estimating the weights in steps 1 and 2 (Supplementary Figure 1).16,21 Candidate variables for Step 1 included items from the survey instrument including: participant demographics, SARSCoV-2 testing and vaccination history, mask use, ability to work remotely, household income, education, whether anyone in the household was considered an essential worker ${ }^{22}$, and any known contacts with a COVID-19 case. Candidate variables also included neighborhood-level characteristics from the 2015 American Community Survey (poverty, crowded living conditions, income, education, and race/ethnicity), ${ }^{17}$ ZIP-code level COVID19 vaccination coverage as of May 2021, and 2020 Presidential general election results by voting precinct. ${ }^{23}$ Finally, we included the Healthy Places Index (HPI), a summary measure of neighborhood conditions that are associated with life-expectancy. ${ }^{24}$ Residents in neighborhoods in HPI quartile 4 have shorter life expectancies compared to those in HPI quartiles 1 to 3 . Because we did not have survey responses from sampled households that never registered for the study, candidate variables for the Step 2 weights were limited to the neighborhood-level characteristics listed above.

We used a cross-validated ensemble machine learning algorithm, SuperLearner, ${ }^{25}$ to estimate inverse probability of selection weights for both Step 1 and Step 2. We included a mixture of parametric and machine learning algorithms in the SuperLearner. Weights for Step 1 were estimated separately for adults and children within each county. Step 2 weights were estimated at the household level within each county. Finally, we used the known sampling probabilities for each invited household to construct the Step 3 weights.

We multiplied all three weights and used iterative proportional fitting (raking) to calibrate the combined weights to ensure that the weighted distribution of age, sex, race/ethnicity, education, household income, and COVID-19 vaccination coverage matched the marginal distributions in the 2015 ACS and the state COVID-19 vaccine registry in each county. ${ }^{26}$

\section{Primary Outcomes}

Participation in CalScope was anonymous, so we could not verify participants' vaccination status. Instead, we used self-reported vaccination status, anti-nucleocapsid, and anti-spike antibody results, to classify participants into 4 mutually exclusive serostatus categories:1) Seronegative: negative nucleocapsid test and negative spike test regardless of self-reported vaccination status; 2) Prior Infection Only: positive nucleocapsid test AND negative spike test OR (positive nucleocapsid test OR positive spike test) AND self-reported not having received any doses of a COVID-19 vaccine; 3 ) Infected and Vaccinated: Positive nucleocapsid test AND positive spike tests AND self-reported at least 1 dose of any COVID- 
19 vaccine; and 4) Vaccinated only: Negative nucleocapsid test AND positive spike test AND self-reported at least 1 dose of any COVID-19 vaccine.

Using the sampling weights, we estimated the proportion of the population in each serostatus category and with evidence of prior infection for the whole sample and stratified by county, age, race/ethnicity, and HPI quartile. We used a non-parametric bootstrap with 1000 replicates to obtain 95\% confidence intervals.

We estimated the ratio of the number of SARS-CoV-2 infections to confirmed cases in the CDPH's COVID-19 case registry in the overall sample and stratified by county for both adults and children. To do this, we divided the proportion of the population with evidence of prior infection in CalScope by the proportion of the population that was a confirmed COVID-19 case as of 14 days prior to the median specimen collection date. A confirmed COVID-19 case was defined as a person with a positive PCR SARS-CoV-2 test; the cutoff date allowed for approximately 14 days between time of infection to seroconversion.

All analyses were conducted in R version 3.6.0 using the sl3 package for SuperLearner implementation, the anesrake package for iterative proportional fitting, and the survey package for analysis of the weighted data. ${ }^{25,27,28}$

\section{RESULTS}

Of the 200,000 households invited, 11,161 registered for the study (5.6\%) (Figure 2). 8,322 (74.6\%) households completed an adult survey and 7,751 households (69\%) completed adult antibody testing. 7,483 (67\%) adults completed the survey and returned a DBS specimen with valid antibody results. Of the 11,161 households that registered for the study, 3,388 (30\%) included at least one eligible child. A total of 2,013 child surveys (65\%) and 1,436 (42.4\%) child antibody tests were completed, and 1,375 (40.6\%) children completed both the survey and an antibody test. Table 1 shows the demographics of the study sample before and after weighting. The median specimen collection date was May 22, 2021, with $60 \%$ of specimens collected in May 2021 and $90 \%$ of specimens collected in May or June 2021. (Supplementary Figure 2)

Spike and Nucleocapsid Seroprevalence

Overall, 6,625/7,483 (89\%) adults and 581/1,375 (42\%) children had detectable spike antibodies; 846/7,483 (11\%) adults and 224/1,375 (16\%) children had detectable nucleocapsid antibodies. The weighted spike seroprevalence was $67 \%$ (95\% CI [63\%,71\%]) for adults and 41\% (95\% CI [35\%, 47\%]) for children; the weighted nucleocapsid seroprevalence was 22\% (95\% CI [18\%, 26\%]) among adults and 25\% (95\% CI [19\%, 31\%]) in children. (Table 2)

\section{Serostatus}

Among adults, we estimated that 33\% (95\% CI [28\%, 37\%]) were seronegative; $18 \%$ (95\% CI [14\%, 22\%]) had antibodies from previous infection but not vaccination; $9 \%$ $(95 \% \mathrm{CI}[6 \%, 11 \%])$ had antibodies from prior infection and vaccination; and 41\% (95\% CI $[37 \%, 45 \%]$ ) had antibodies from vaccination alone. (Table 3) Among children, 57\% (95\% 
CI [48\%, 67\%]) were seronegative; 26\% (95\% CI [19\%, 32\%]) had antibodies from prior infection but not vaccination; $5 \%$ (95\% CI [1\%, 8\%]) had antibodies from prior infection and vaccination; and 13\% (95\% CI [7\%, 18\%]) had antibodies from vaccination alone. (Table 4) There was considerable regional heterogeneity in serostatus for adults and children across the seven counties. For example, seronegativity in adults varied from $27 \%$ (95\% CI [15\%, 38\%]) in Monterey county to 42\% (95\% CI [29\%, 54\%]) in El Dorado county. For children, seronegativity ranged from 51\% (95\% CI [34\%, 67\%]) in Los Angeles County to $68 \%$ (95\% CI $[41 \%, 96 \%])$ in El Dorado County.

Serostatus also varied across age groups, with the lowest susceptibility among people $>65$ years $(28 \%, 95 \% \mathrm{CI}[17 \%, 40 \%])$ and highest proportion seronegative in children $<5$ years old (71\%, 95\% CI [40\%, 100\%]). Seropositivity due to vaccination alone was highest in people $>65$ years $(59 \%, 95 \%$ CI [48\%, 69\%]) whereas people between ages 18 and 25 years were more likely to have antibodies from prior infection alone $(33 \%, 95 \%$ CI $[11 \%, 54 \%])$. When comparing across race and ethnicity, the lowest percent seronegative was in Latinx adults (24\%, 95\% CI [17\%, 46\%]); non-Latinx Asian adults were most likely to have antibodies due to vaccination alone (53\%, 95\% CI [44\%, 61\%]). (Table 3)

Finally, adults living in HPI quartiles 1 or 4 were less likely to be seronegative than adults living in HPI quartiles 2 or 3. (Table 3) In contrast, children living in HPI quartile 1 were less likely to be seronegative compared to those in the higher HPI quartiles. (Table 4)

\section{Evidence of Prior Infection and Infection-to-Case Ratio}

Overall, 27\% (95\% CI [23\%, 31\%]) of adults and 30\% (95\% CI [24\%, 36\%]) of children had evidence of prior infection. In contrast, $11 \%$ of adults and $6 \%$ of children were confirmed COVID-19 cases as of May 8, 2021 in the COVID-19 case registry in the seven CalScope counties. The estimated infection-to-case ratio was 2.6 (95\% CI [2.2, 2.9]) for adults and 5.0 (95\% CI [4.0, 5.0]) for children. (Figure 3)

Evidence of prior infection among adults varied across the seven counties from 14\% (95\% CI [8\%, 20\%]) in El Dorado County to 30\% (95\% CI [24\%,36\%]) in Los Angeles County. Similarly, the percent of children with antibody evidence of prior infection varied from $15 \%$ (95\% CI [1\%, 29\%]) in Alameda County to 39\% (95\% CI [19\%, 59\%]) in Monterey County. Infection-to-case ratios were consistently higher for children than adults in all counties.

Adults 18-25 years old were most likely to have evidence of prior infection (40\%, 95\% CI [18\%, 62\%]). (Table 3) Among children, those between 5 and 11 years old were most likely to have evidence of prior infection (36\%, 95\% CI [21\%, 51\%]). (Table 4) Adults $>65$ years were least likely to have evidence of prior infection $(13 \%, 95 \%$ CI [7\%, 19\%]).

Latinx adults and children were more likely to have antibodies from prior infection (adults: 36\%, 95\% CI [27\%, 45\%]; children: 35\%, 95\% CI [23\%, 46\%]) compared with non-Latinx adults or children, and non-Latinx Asian adults and children were least likely to 
have antibody evidence of prior infection (adults: 21\%, 95\% CI [12\%, 30\%]; children: 21\%, 95\%CI [3\%, 39\%]).

Finally, seroprevalence of antibodies from prior infection was highest among adults and children living in the lowest HPI quartile and was lowest in adults and children living in neighborhoods in the highest HPI quartile.

\section{DISCUSSION}

During Wave 1 of CalScope, $33 \%$ of adults and $56 \%$ of children did not have antibodies against SARS-CoV-2 as of June 2021 , with $27 \%$ of adults and $30 \%$ of children having evidence of prior SARS-CoV-2 infection. Overall, the infection-to-case ratio was 2.6 for adults and 5.0 for children suggesting that through June 2021, similar numbers of infections had occurred in adults and children, but infections in children were less likely to be diagnosed because of less widespread testing in children.

Serostatus differed across region, race/ethnicity, age, and HPI quartile reflecting disparate patterns of infection and vaccination. For example, California has been prioritizing equity in its COVID-19 response by using the HPI to target vaccination campaigns, testing, and other COVID-19 mitigation measures towards more disadvantaged neighborhoods, which have borne a larger burden of the COVID-19 pandemic thus far. ${ }^{29}$ Our results suggest that these targeted vaccination campaigns have been effective seropositivity due to vaccination is similar for adults in the lowest and highest HPI quartiles (56\% in both).

To the best of our knowledge, this is the first study to conduct population-based serological testing of children under 18 in the United States. Though the proportion of children and adults who had been previously infected was similar, most children remained seronegative as of June 2021 because they were not yet eligible for vaccination. Even among those eligible (age 12-17), vaccination coverage has been low, and many were still seronegative. With in-person schooling resuming in much of the state, it will be important to encourage vaccination of all age eligible children.

The ADAP assays used in CalScope are highly sensitive and specific, but the assays have only been validated up to 4 months post-infection. Thus, we do not know the extent of antibody waning below the limit of detection after $>4$ months. This means that our estimates of seroprevalence due to prior infection might underestimate true cumulative incidence-particularly in populations who were infected in the Spring of 2020. Additionally, individuals whose antibodies wane below detectable levels after vaccination or infection may not be equally susceptible to subsequent infection or COVID-19 disease as immunologically naïve individuals because of cell-mediated immunity. ${ }^{30}$ So, our seroprevalence estimates may underestimate the proportion of the population with immunity.

We anticipated that those who enrolled in our study might not be representative of our target populations, so we used causal transportability to design our study and survey instrument to generalize our results to our target populations. Our weighted results can be 
medRxiv preprint doi: https://doi.org/10.1101/2021.12.09.21267565; this version posted December 11, 2021. The copyright holder for this preprint (which was not certified by peer review) is the author/funder, who has granted medRxiv a license to display the preprint in perpetuity.

It is made available under a CC-BY-NC-ND 4.0 International license .

considered unbiased estimates of SARS-CoV-2 serostatus in our target population if we assume that we were able to measure and adjust for all the differences between the study sample and target population that were associated with SARS-CoV-2 serostatus. If our weights excluded any key characteristics that differed between the sample and target population and that affected SARS-CoV-2 serostatus, our results might still suffer from residual non-response bias. However, our estimates are in line with those from other studies and known patterns of vaccination and infection, so residual biases are unlikely to meaningfully affect our results.

Overall, we found that similar proportions of adults and children had been infected through June 2021, but serostatus varied substantially across region, age group, and by race/ethnicity. Though seroprevalence studies such as CalScope are unable to measure all aspects of the immune response, spike antibodies are a correlate of protection for SARS$\mathrm{CoV}-2$ infection and symptomatic disease. ${ }^{31-33}$ As vaccination and transmission continues, the population that remains most vulnerable to COVID-19 infection and disease will evolve. It is critical that public health agencies monitor who does not have SARS-CoV-2 antibodies to accurately forecast future COVID-19 surges. CalScope will begin collecting data for Wave 2 in Fall 2021 and Wave 3 will occur in the first half of 2022. 
medRxiv preprint doi: https://doi.org/10.1101/2021.12.09.21267565; this version posted December 11, 2021. The copyright holder for this preprint (which was not certified by peer review) is the author/funder, who has granted medRxiv a license to display the preprint in perpetuity.

It is made available under a CC-BY-NC-ND 4.0 International license .

\section{ACKNOWLEDGEMENTS}

We thank Daniela Valenzuela, Evelyn Cubias, Mauricio Ollervides, Edgar Martinez, Kara Gionfriddo, Lourdes Mariana Ponte-Cordova, and Stefanie Medlin for their work in addressing participant questions and concerns. We thank Thomas Quarre and Siddarth Satish for their support in designing and maintaining the CalScope website. The study was funded by a CDC ELC grant to the California Department of Public Health. 
medRxiv preprint doi: https://doi.org/10.1101/2021.12.09.21267565; this version posted December 11, 2021. The copyright holder for this preprint (which was not certified by peer review) is the author/funder, who has granted medRxiv a license to display the preprint in perpetuity.

It is made available under a CC-BY-NC-ND 4.0 International license .

\section{REFERENCES}

1 United States COVID-19 Cases and Deaths by State over Time | Data | Centers for Disease Control and Prevention. https://data.cdc.gov/Case-Surveillance/United-States-COVID19-Cases-and-Deaths-by-State-o/9mfq-cb36 (accessed 0ct 4, 2021).

2 CalCAT. https://calcat.covid19.ca.gov/cacovidmodels/ (accessed 0ct 4, 2021).

3 Baden LR, El Sahly HM, Essink B, et al. Efficacy and Safety of the mRNA-1273 SARS-CoV-2 Vaccine. New England Journal of Medicine 2021; 384: 403-16.

4 Polack FP, Thomas SJ, Kitchin N, et al. Safety and Efficacy of the BNT162b2 mRNA Covid19 Vaccine. New England Journal of Medicine 2020; 383: 2603-15.

5 Gazit S, Shlezinger R, Perez G, et al. Comparing SARS-CoV-2 natural immunity to vaccineinduced immunity: reinfections versus breakthrough infections. Infectious Diseases (except HIV/AIDS), 2021 D0I:10.1101/2021.08.24.21262415.

6 Lamba K, Bradley H, Shioda K, et al. SARS-CoV-2 Cumulative Incidence and Period Seroprevalence: Results From a Statewide Population-Based Serosurvey in California. Open Forum Infectious Diseases 2021; 8. DOI:10.1093/ofid/ofab379.

7 Robertson MM, Kulkarni SG, Rane M, et al. Cohort profile: a national, community-based prospective cohort study of SARS-CoV-2 pandemic outcomes in the USA-the CHASING COVID Cohort study. BMJ Open 2021; 11: e048778.

8 Siegler AJ, Sullivan PS, Sanchez T, et al. Protocol for a national probability survey using home specimen collection methods to assess prevalence and incidence of SARS-CoV-2 infection and antibody response. Annals of Epidemiology 2020; 49: 50-60.

9 Sullivan PS, Siegler AJ, Shioda K, et al. Severe Acute Respiratory Syndrome Coronavirus 2 Cumulative Incidence, United States, August 2020-December 2020. Clinical Infectious Diseases 2021; published online July 10. D0I:10.1093/cid/ciab626.

10 Bajema KL, Wiegand RE, Cuffe K, et al. Estimated SARS-CoV-2 Seroprevalence in the US as of September 2020. JAMA Intern Med 2020; published online Nov 24. DOI:10.1001/jamainternmed.2020.7976.

11 Havers FP, Reed C, Lim T, et al. Seroprevalence of Antibodies to SARS-CoV-2 in 10 Sites in the United States, March 23-May 12, 2020. JAMA Intern Med 2020; published online July 21. DOI:10.1001/jamainternmed.2020.4130.

12 Ng DL, Goldgof GM, Shy BR, et al. SARS-CoV-2 seroprevalence and neutralizing activity in donor and patient blood. Nature Communications 2020; 11: 4698.

13 Anand S, Montez-Rath M, Han J, et al. Prevalence of SARS-CoV-2 antibodies in a large nationwide sample of patients on dialysis in the USA: a cross-sectional study. Lancet 2020; 396: 1335-44. 
medRxiv preprint doi: https://doi.org/10.1101/2021.12.09.21267565; this version posted December 11, 2021. The copyright holder for this preprint (which was not certified by peer review) is the author/funder, who has granted medRxiv a license to display the preprint in perpetuity.

It is made available under a CC-BY-NC-ND 4.0 International license .

14 Bendavid E, Mulaney B, Sood N, et al. COVID-19 antibody seroprevalence in Santa Clara County, California. International Journal of Epidemiology 2021; 50: 410-9.

15 Sood N, Simon P, Ebner P, et al. Seroprevalence of SARS-CoV-2-Specific Antibodies Among Adults in Los Angeles County, California, on April 10-11, 2020. JAMA 2020; 323: 2425-7.

16 Pearl J, Bareinboim E. Transportability of Causal and Statistical Relations: A Formal Approach. In: 2011 IEEE 11th International Conference on Data Mining Workshops. Vancouver, BC, Canada: IEEE, 2011: 540-7.

17 U.S. Census Bureau. American Community Survey (2015). 2015.

18 Karp DG, Danh K, Espinoza NF, Seftel D, Robinson PV, Tsai C. A serological assay to detect SARS-CoV-2 antibodies in at-home collected finger-prick dried blood spots. Sci Rep 2020; 10: 20188.

19 Pearl J, Bareinboim E. External Validity: From Do-Calculus to Transportability Across Populations. Statistical Science 2014; 29: 579-95.

20 Cole SR, Stuart EA. Generalizing Evidence From Randomized Clinical Trials to Target Populations: The ACTG 320 Trial. American Journal of Epidemiology (England) 2010; 172: 107-15.

21 Petersen ML. Compound Treatments, Transportability, and the Structural Causal Model: The Power and Simplicity of Causal Graphs. Epidemiology (Cambridge, Mass) 2011; 22: 378-81.

22 California S of. Essential workforce. https://covid19.ca.gov/essential-workforce/ (accessed Oct 6, 2021).

23 Statewide Database. 2020 General Election Precinct Data. www.statewidedatabase.org/d10/g20.html (accessed Aug 5, 2021).

24 Public Health Alliance of Southern California. The California Healthy Places Index (HPI). 2021; published online April 22. www.healthyplaces.org (accessed Aug 5, 2021).

25 van der Laan MJ, Rose S. Targeted Learning. New York, NY: Springer New York, 2011 http://link.springer.com/10.1007/978-1-4419-9782-1 (accessed 0ct 23, 2016).

26 Bacharach M. Estimating Nonnegative Matrices from Marginal Data. International Economic Review 1965; 6: 294-310.

27 Pipelines for Machine Learning and Super Learning. https://tlverse.org/sl3/index.html (accessed Oct 5, 2021).

28 R Core Team. R: A Language and Environment for Statistical Computing. Vienna, Austria: R Foundation for Statistical Computing, 2018 https://www.R-project.org/. 
29 Blueprint for a Safer Economy. https://www.cdph.ca.gov/Programs/CID/DCDC/Pages/COVID19/COVID19CountyMonitoringOverview.aspx (accessed Oct 5, 2021).

30 Cassaniti I, Percivalle E, Bergami F, et al. SARS-CoV-2 specific T-cell immunity in COVID-19 convalescent patients and unexposed controls measured by ex vivo ELISpot assay. Clinical Microbiology and Infection 2021; 27: 1029-34.

31 Corbett KS, Nason MC, Flach B, et al. Immune correlates of protection by mRNA1273 vaccine against SARS-CoV-2 in nonhuman primates. Science; 373: eabj0299.

32 Harvey RA, Rassen JA, Kabelac CA, et al. Association of SARS-CoV-2 Seropositive Antibody Test With Risk of Future Infection. JAMA Internal Medicine 2021; 181: 672-9.

33 Addetia A, Crawford KHD, Dingens A, et al. Neutralizing Antibodies Correlate with Protection from SARS-CoV-2 in Humans during a Fishery Vessel Outbreak with a High Attack Rate. J Clin Microbiol 2020; 58: e02107-20. 
medRxiv preprint doi: https://doi.org/10.1101/2021.12.09.21267565; this version posted December 11, 2021. The copyright holder for this preprint (which was not certified by peer review) is the author/funder, who has granted medRxiv a license to display the preprint in perpetuity.

It is made available under a CC-BY-NC-ND 4.0 International license .

\section{FIGURE 1}

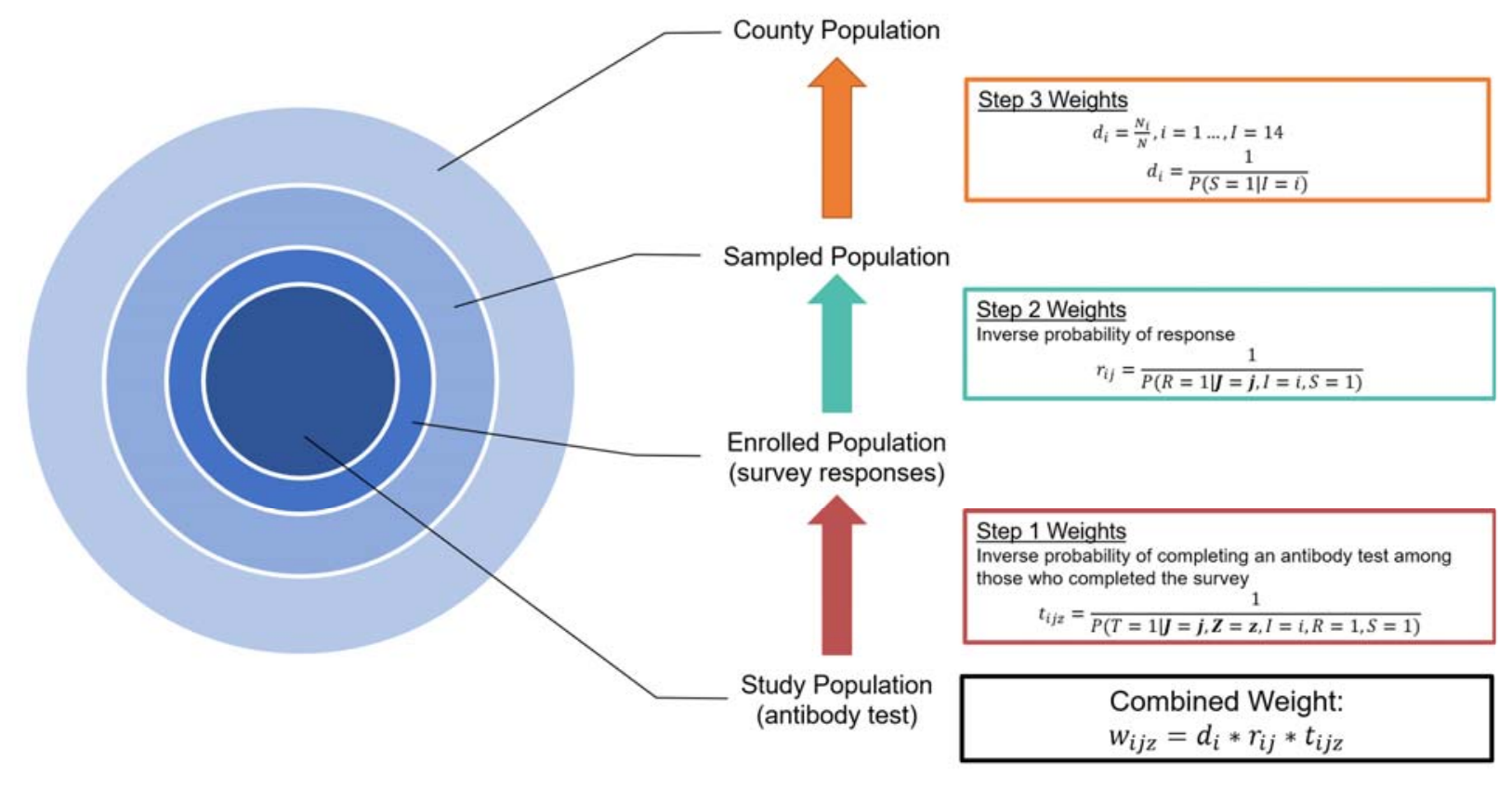

Figure 1. Levels of selection between study sample and target population in each county and corresponding weighting steps. In the Step 3 Weights, $S=1$ indicates that the household was sampled and $\mathrm{I}=\mathrm{i}$ is the sampling stratum. In the Step 2 Weights, $\mathrm{R}=1$ indicates that at least one member of the household completed a survey instrument (enrolled). J is a vector of address-based characteristics including demographic characteristics from the American Community Survey, Healthy Places Index quartile, 2020 Presidential Election results by voter precinct, and COVID-19 vaccination coverage as of April 20, 2021 by zip code. In the Step 1 Weights, $\mathbf{T}=1$ indicates that an individual has a valid antibody test result, $\mathbf{Z}$ is a vector of individual-level measurements from the survey instrument. Step 3 and 2 weights were estimated at the household level. Step 1 weights were estimated at the individual level with weights estimated separately for adults and children. The combined weight is the product of all 3 weights. 
medRxiv preprint doi: https://doi.org/10.1101/2021.12.09.21267565; this version posted December 11, 2021. The copyright holder for this preprint (which was not certified by peer review) is the author/funder, who has granted medRxiv a license to display the preprint in perpetuity.

It is made available under a CC-BY-NC-ND 4.0 International license .

\section{FIGURE 2}

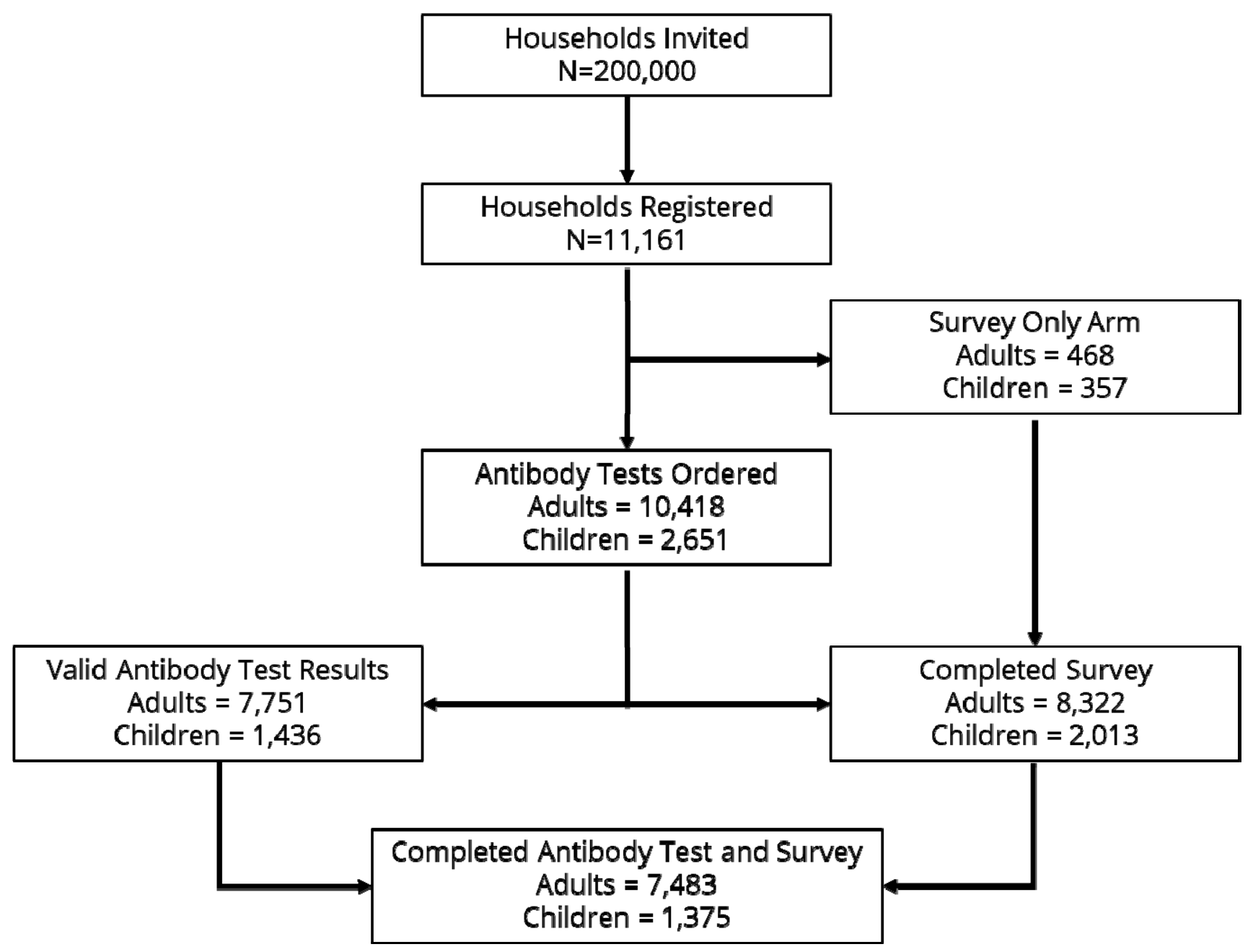

Figure 2. Wave 1 Consort Diagram. The final study sample includes those who completed an antibody test and survey instrument. 
medRxiv preprint doi: https://doi.org/10.1101/2021.12.09.21267565; this version posted December 11, 2021. The copyright holder for this preprint (which was not certified by peer review) is the author/funder, who has granted medRxiv a license to display the preprint in perpetuity.

It is made available under a CC-BY-NC-ND 4.0 International license .

\section{FIGURE 3}

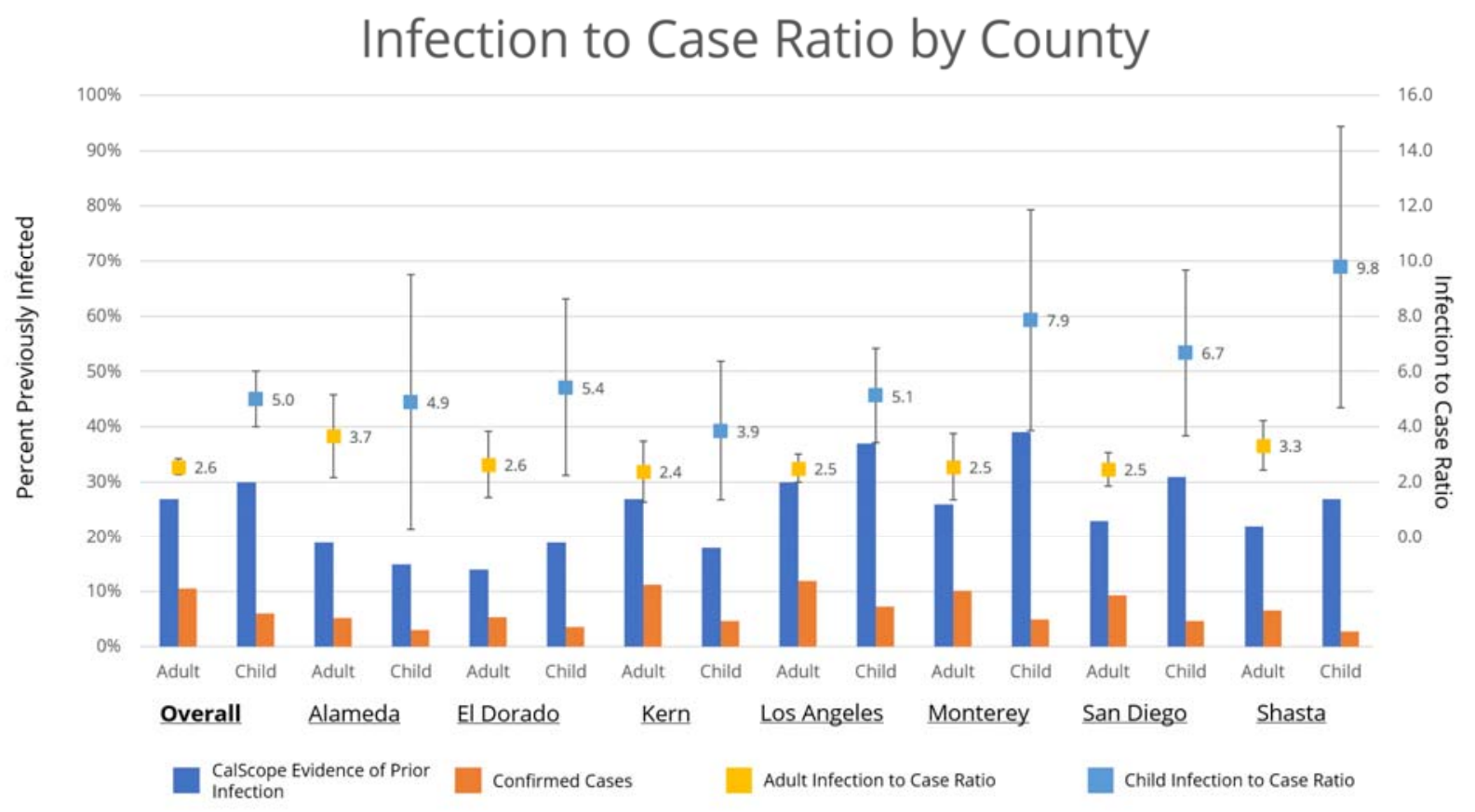

Figure 3. Infection to Case Ratio by County. The infection to case ratio is the ratio of the percent of the population with evidence of prior infection based on antibody test results to the percent of the population with a PCR-confirmed infection in CDPH's COVID-19 surveillance database with an episode date on or before May 8, 2020. 
medRxiv preprint doi: https://doi.org/10.1101/2021.12.09.21267565; this version posted December 11, 2021. The copyright holder for this preprint (which was not certified by peer review) is the author/funder, who has granted medRxiv a license to display the preprint in perpetuity.

It is made available under a CC-BY-NC-ND 4.0 International license .

TABLE 1. Study Sample

\begin{tabular}{|c|c|c|c|c|c|}
\hline \multirow{2}{*}{\multicolumn{2}{|c|}{ Characteristic }} & \multicolumn{2}{|c|}{ Sample } & \multicolumn{2}{|c|}{ Weighted Sample } \\
\hline & & $\mathrm{N}$ & Percent & $\mathrm{N}$ & Percent \\
\hline & Overall & 7483 & 100 & 13691938 & 100 \\
\hline \multirow{7}{*}{ County } & Alameda & 1012 & 13.5 & 1673845 & 12.2 \\
\hline & El Dorado & 803 & 10.7 & 180384 & 1.3 \\
\hline & Kern & 343 & 4.6 & 671452 & 4.9 \\
\hline & Los Angeles & 2225 & 29.7 & 7810740 & 57.0 \\
\hline & Monterey & 724 & 9.7 & 332740 & 2.4 \\
\hline & San Diego & 1650 & 22.0 & 2877651 & 21.0 \\
\hline & Shasta & 726 & 9.7 & 145126 & 1.1 \\
\hline \multirow{4}{*}{ Age } & $18-25$ & 285 & 3.8 & 1083541 & 7.9 \\
\hline & $26-40$ & 1683 & 22.5 & 3673681 & 26.8 \\
\hline & $41-65$ & 3458 & 46.2 & 6795184 & 49.6 \\
\hline & $65+$ & 2057 & 27.5 & 2139532 & 15.6 \\
\hline \multirow{5}{*}{ Race/Ethnicity } & Latino & 1133 & 15.1 & 6564547 & 47.9 \\
\hline & NH White & 4710 & 62.9 & 3786745 & 27.7 \\
\hline & NH Asian & 811 & 10.8 & 1625260 & 11.9 \\
\hline & NH Black & 319 & 4.3 & 752348 & 5.5 \\
\hline & Other & 510 & 6.9 & 963038 & 7.0 \\
\hline \multirow{4}{*}{ Healthy Places Index } & Quartile 1 & 994 & 13.3 & 4629711 & 33.8 \\
\hline & Quartile 2 & 2168 & 29.0 & 3976184 & 29.0 \\
\hline & Quartile 3 & 1943 & 26.0 & 2955262 & 21.6 \\
\hline & Quartile 4 & 2378 & 31.8 & 2130781 & 15.6 \\
\hline \multirow{6}{*}{ Education } & Less than high school & 114 & 1.5 & 2077099 & 15.2 \\
\hline & $\begin{array}{r}\text { High school/General Educational } \\
\text { Development (GED) }\end{array}$ & 500 & 6.7 & 3327150 & 24.3 \\
\hline & Some college & 1975 & 26.4 & 3859666 & 28.2 \\
\hline & Bachelor's degree & 2454 & 32.8 & 2777891 & 20.3 \\
\hline & Master's degree or higher & 2323 & 31.0 & 1579927 & 11.5 \\
\hline & (Missing) & 117 & 1.6 & 70204 & 0.5 \\
\hline \multirow{2}{*}{ Assigned Sex at Birth } & Female & 4475 & 59.8 & 7201959 & 52.6 \\
\hline & Male & 3008 & 40.2 & 6489979 & 47.4 \\
\hline \multirow{5}{*}{ Household Income } & $<\$ 25 k$ & 885 & 11.8 & 3768643 & 31.9 \\
\hline & $\$ 25 k-\$ 75 k$ & 2110 & 28.2 & 4886015 & 41.4 \\
\hline & $\$ 75 k-\$ 100 k$ & 1060 & 14.2 & 1588511 & 13.5 \\
\hline & $\$ 100 k-\$ 150 k$ & 1524 & 20.4 & 1645576 & 13.9 \\
\hline & $>\$ 150 \mathrm{~K}$ & 1904 & 25.4 & 1803192 & 15.3 \\
\hline \multirow{2}{*}{ Crowded Living Conditions } & Yes & 528 & 7.1 & 1382886 & 10.1 \\
\hline & No & 6955 & 92.9 & 12309052 & 89.9 \\
\hline
\end{tabular}


medRxiv preprint doi: https://doi.org/10.1101/2021.12.09.21267565; this version posted December 11, 2021. The copyright holder for this preprint (which was not certified by peer review) is the author/funder, who has granted medRxiv a license to display the preprint in perpetuity.

It is made available under a CC-BY-NC-ND 4.0 International license .

\section{TABLE 2. Nucleocapsid and Spike Results}

TABLE 2. NUCLEOCAPSID AND SPIKE ANTIBODY TEST RESULTS

\begin{tabular}{|c|c|c|c|c|c|c|c|c|c|c|c|}
\hline & & \multicolumn{5}{|c|}{ Nucleocapsid } & \multicolumn{5}{|c|}{ Spike } \\
\hline & & \multicolumn{3}{|c|}{ Unweighted } & \multicolumn{2}{|c|}{ Weighted } & \multicolumn{3}{|c|}{ Unweighted } & \multicolumn{2}{|c|}{ Weighted } \\
\hline & & $\mathrm{n}$ & $\mathrm{N}$ & $\%$ & Seroprevalence & $95 \% \mathrm{Cl}$ & $\mathrm{n}$ & $\mathrm{N}$ & $\%$ & Seroprevalence & $95 \% \mathrm{Cl}$ \\
\hline \multirow{2}{*}{ Overall } & Adult & 846 & 7483 & $11 \%$ & $22 \%$ & {$[18 \%, 26 \%]$} & 6625 & 7483 & $89 \%$ & $67 \%$ & {$[63 \%, 71 \%]$} \\
\hline & Child & 224 & 1375 & $16 \%$ & $25 \%$ & {$[19 \%, 31 \%]$} & 581 & 1375 & $42 \%$ & $41 \%$ & {$[35 \%, 47 \%]$} \\
\hline \multirow{2}{*}{ Alameda } & Adult & 51 & 1012 & $5 \%$ & $10 \%$ & {$[4 \%, 16 \%]$} & 959 & 1012 & $95 \%$ & $69 \%$ & {$[61 \%, 77 \%]$} \\
\hline & Child & 14 & 165 & $8 \%$ & $13 \%$ & {$[0 \%, 29 \%]$} & 74 & 165 & $45 \%$ & $27 \%$ & {$[7 \%, 47 \%]$} \\
\hline \multirow{2}{*}{ EI Dorado } & Adult & 70 & 803 & $9 \%$ & $10 \%$ & {$[4 \%, 16 \%]$} & 694 & 803 & $86 \%$ & $58 \%$ & {$[48 \%, 68 \%]$} \\
\hline & Child & 24 & 162 & $15 \%$ & $17 \%$ & {$[5 \%, 29 \%]$} & 73 & 162 & $45 \%$ & $30 \%$ & {$[16 \%, 44 \%]$} \\
\hline \multirow{2}{*}{ Kern } & Adult & 60 & 343 & $17 \%$ & $25 \%$ & {$[13 \%, 37 \%]$} & 285 & 343 & $83 \%$ & $61 \%$ & {$[45 \%, 77 \%]$} \\
\hline & Child & 22 & 84 & $26 \%$ & $16 \%$ & {$[4 \%, 28 \%]$} & 41 & 84 & $49 \%$ & $36 \%$ & {$[14 \%, 58 \%]$} \\
\hline \multirow{2}{*}{ Los Angeles } & Adult & 323 & 2225 & $15 \%$ & $26 \%$ & {$[20 \%, 32 \%]$} & 2004 & 2225 & $90 \%$ & $68 \%$ & {$[62 \%, 74 \%]$} \\
\hline & Child & 84 & 429 & $20 \%$ & $34 \%$ & {$[22 \%, 46 \%]$} & 193 & 429 & $45 \%$ & $49 \%$ & {$[37 \%, 61 \%]$} \\
\hline \multirow{2}{*}{ Monterey } & Adult & 70 & 724 & $10 \%$ & $24 \%$ & {$[14 \%, 34 \%]$} & 659 & 724 & $91 \%$ & $73 \%$ & {$[63 \%, 83 \%]$} \\
\hline & Child & 23 & 115 & $20 \%$ & $30 \%$ & {$[10 \%, 50 \%]$} & 56 & 115 & $49 \%$ & $45 \%$ & {$[23 \%, 67 \%]$} \\
\hline \multirow{2}{*}{ San Diego } & Adult & 168 & 1650 & $10 \%$ & $19 \%$ & {$[13 \%, 25 \%]$} & 1442 & 1650 & $87 \%$ & $65 \%$ & {$[59 \%, 71 \%]$} \\
\hline & Child & 37 & 311 & $12 \%$ & $19 \%$ & {$[7 \%, 31 \%]$} & 98 & 311 & $32 \%$ & $40 \%$ & {$[26 \%, 54 \%]$} \\
\hline \multirow{2}{*}{ Shasta } & Adult & 104 & 726 & $14 \%$ & $19 \%$ & {$[13 \%, 25 \%]$} & 582 & 726 & $80 \%$ & $63 \%$ & {$[55 \%, 71 \%]$} \\
\hline & Child & 20 & 109 & $18 \%$ & $23 \%$ & {$[11 \%, 35 \%]$} & 46 & 109 & $42 \%$ & $36 \%$ & {$[22 \%, 50 \%]$} \\
\hline
\end{tabular}


TABLE 3.

TABLE 3. ADULT SEROSTATUS BY REGION, AGE, RACE/ETHNICITY, AND HPI QUARTILE

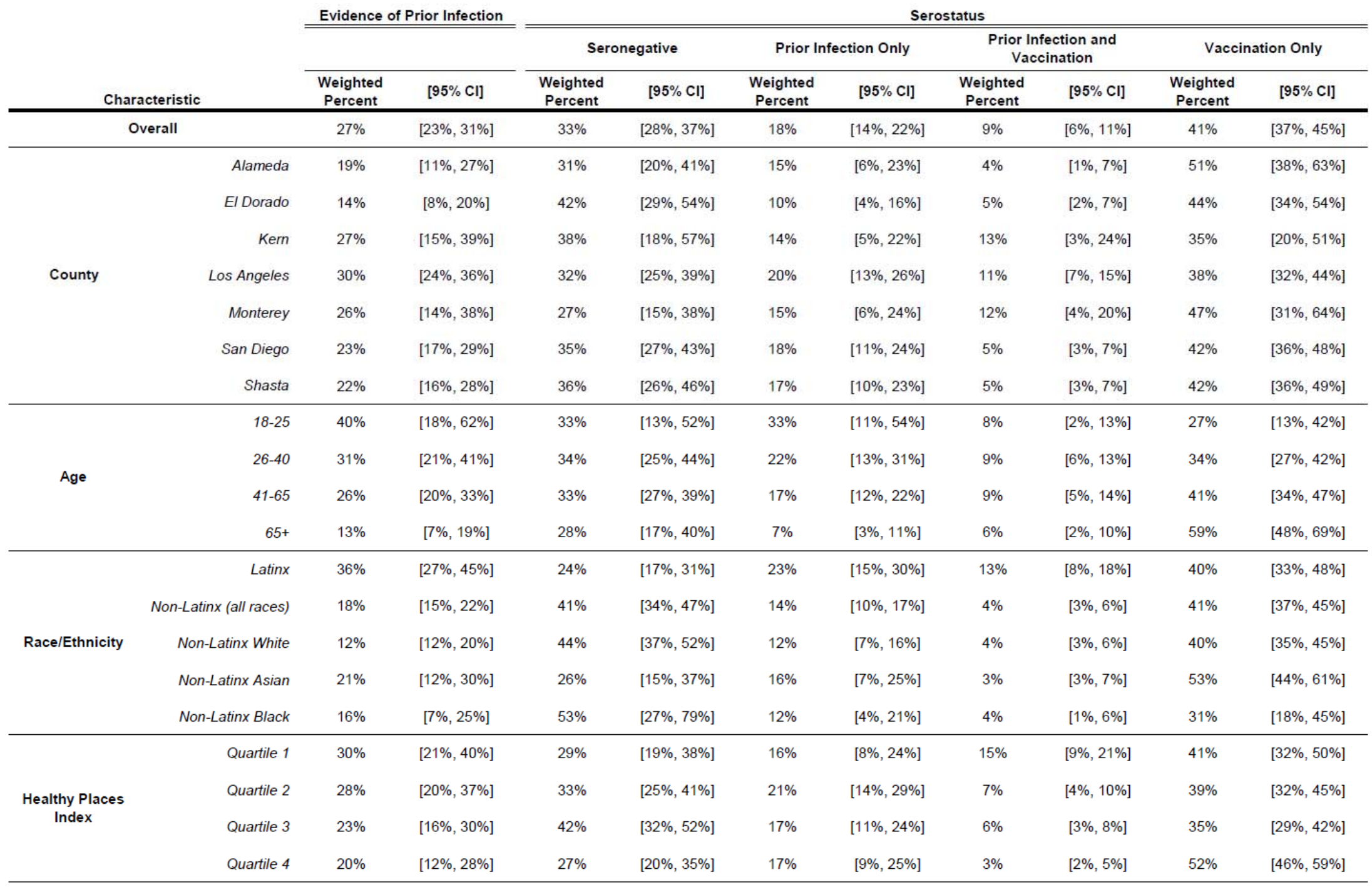


TABLE 4.

TABLE 4. CHILD SEROSTATUS BY REGION, AGE, RACE/ETHNICITY, AND HPI QUARTILE

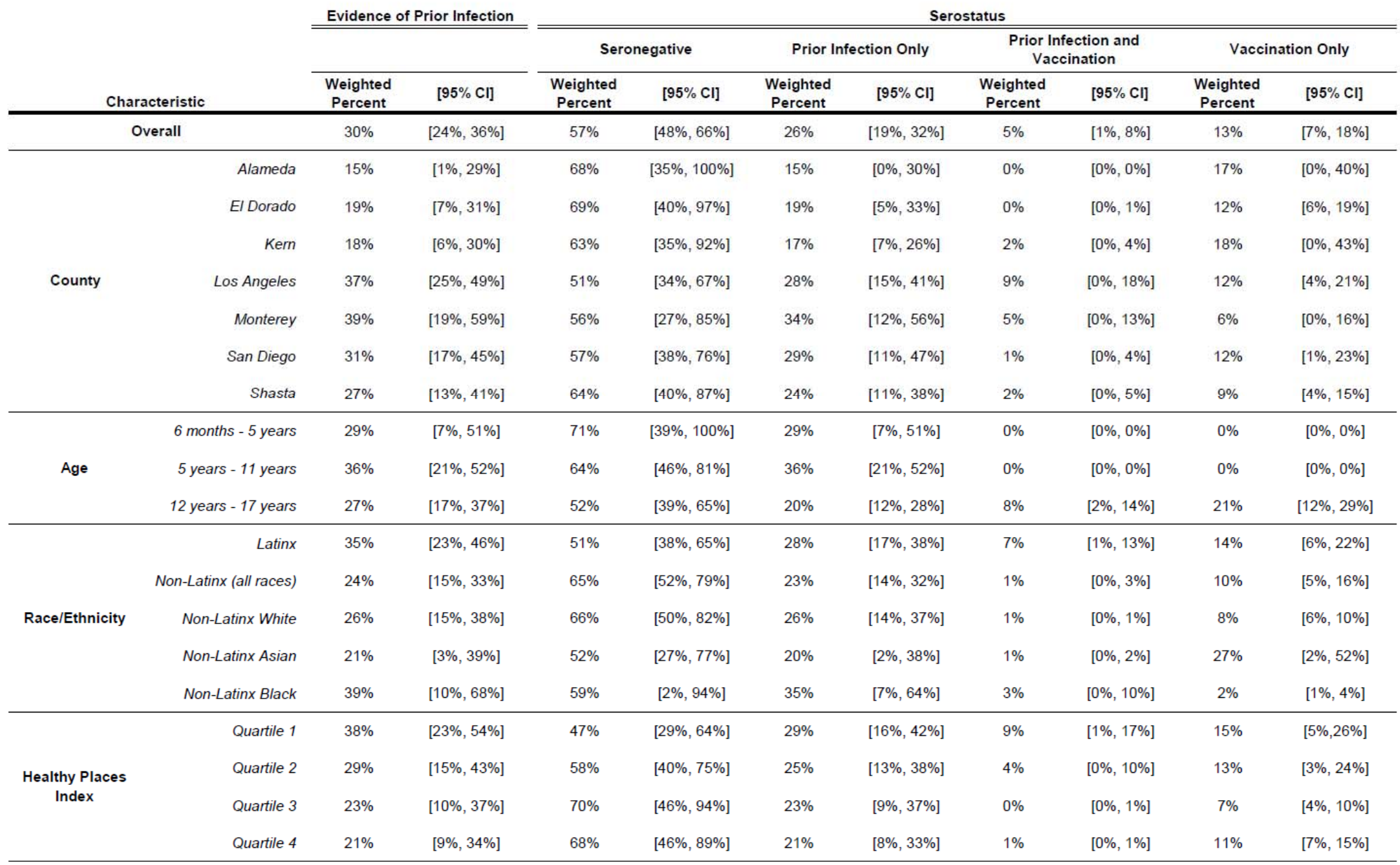


SUPPLEMENTARY FIGURE 1

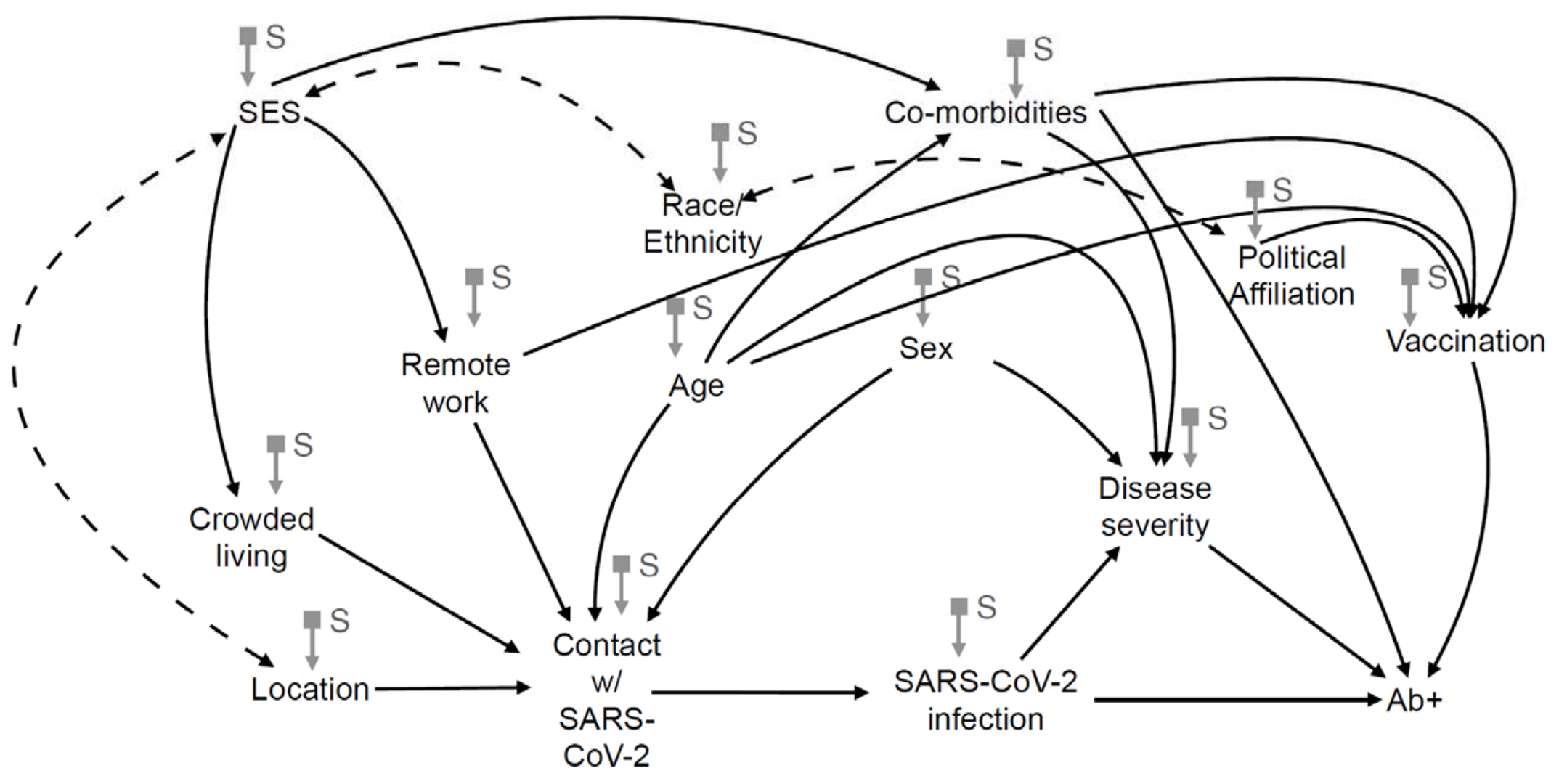




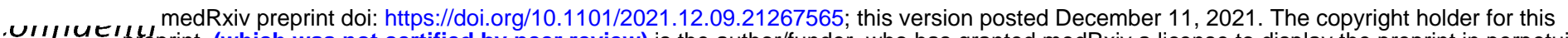

'ṕéprint (which was not certified by peer review) is the author/funder, who has granted medRxiv a license to display the preprint in perpetuity.

\section{SUPPLEMENTARY FIGURE 2}

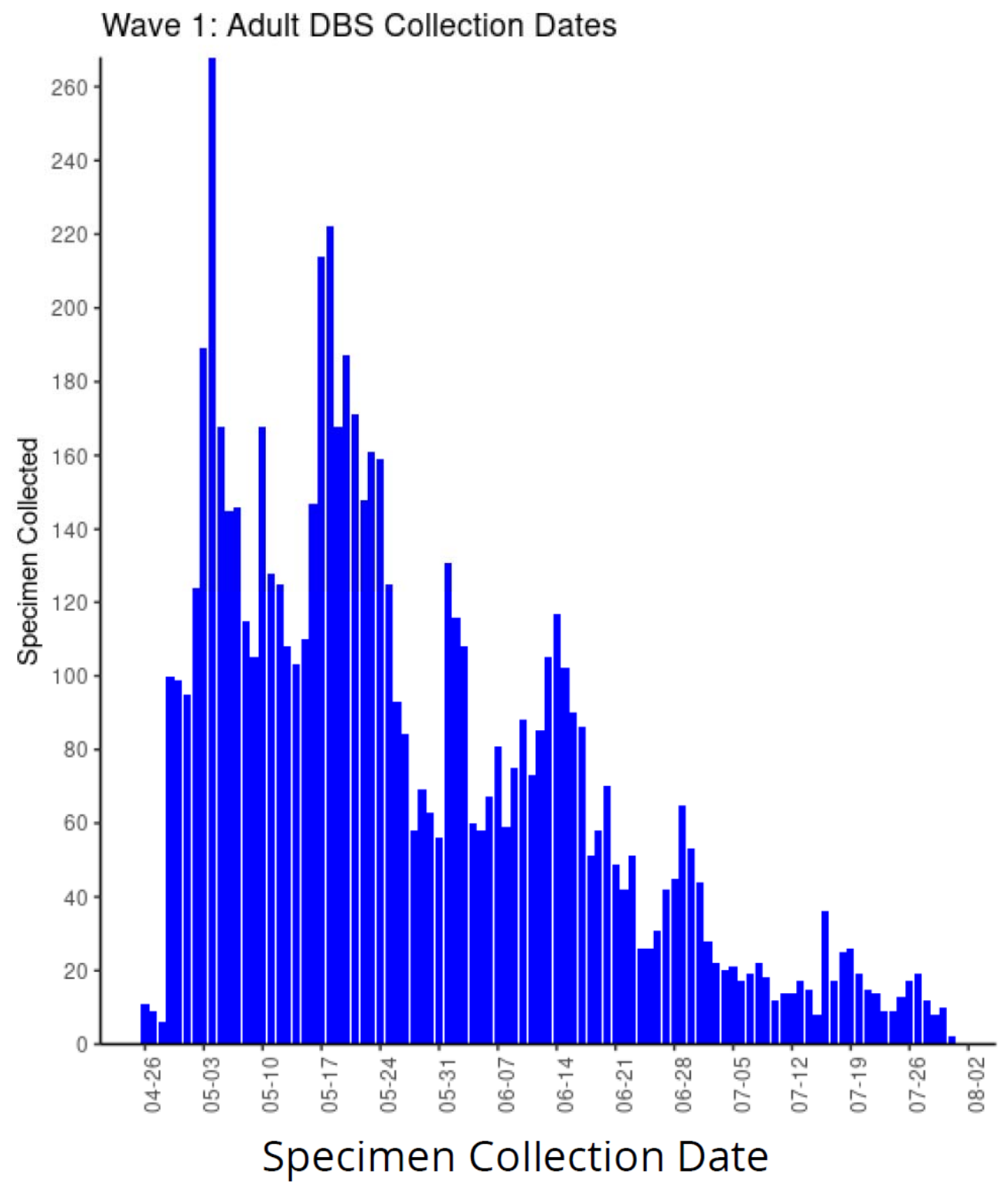




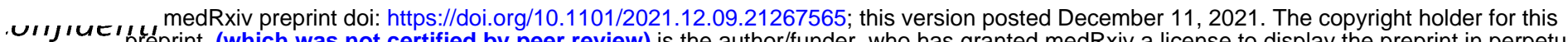

It is made available under a CC-BY-NC-ND 4.0 International license .

\section{APPENDIX}

\section{COUNTY SELECTION}

First, we divided the state into 7 mutually exclusive geographic regions such that the counties within each region were similar with respect to SARS-CoV-2 cumulative confirmed cases and known risk factors for SARS-CoV-2. Cumulative confirmed cases were based on PCR-confirmed COVID-19 cases in the California's COVID-19 surveillance database as of November 2020. Census-tract level measures hypothesized to be associated with prior and ongoing SARS-CoV-2 infection risk included poverty and crowded living conditions derived from the 2015 American Community Survey and the University of California San Francisco Health Atlas ${ }^{1,2}$

Next, one county was selected to represent each region. To ensure that estimates from each county could be generalized to their respective regions, we selected the county that was most heterogeneous with respect to SARS-CoV-2 risk factors, race, ethnicity, age, and cumulative confirmed COVID-19 cases relative to the other counties within the region. ${ }^{3}$ 


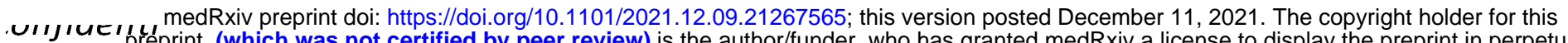

It is made available under a CC-BY-NC-ND 4.0 International license .

\section{ASSAY PROCEDURES}

Complete details of the ADAP assay have been published previously. ${ }^{4}$ The DBS specimen were eluted by punching six $3 \mathrm{~mm}$ discs into $1 \mathrm{~mL}$ of elution buffer and incubating at $37^{\circ} \mathrm{C}$ for $90 \mathrm{~min}$. The eluents were then concentrated with $100 \mathrm{kD}$ MWCO filter column at 14,000 rcf for $9 \mathrm{~min}$. The eluents were then mixed with spike and nucleocapsid protein-DNA conjugates, followed with enzymatic ligation to reunite nearby DNA within the antibodyantigen immune complex. The ligated products were then amplified with PCR and quantified with specific primers in 384-well qPCR. 


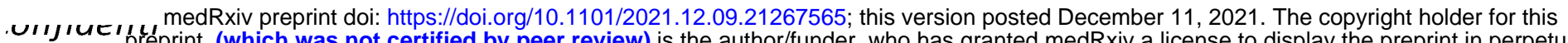
ṕléprint (which was not certified by peer review) is the author/funder, who has granted medRxiv a license to display the preprint in perpetuity.

It is made available under a CC-BY-NC-ND 4.0 International license .

\section{APPENDIX REFERENCES}

1. Emeruwa UN, Ona S, Shaman JL, et al. Associations Between Built Environment, Neighborhood Socioeconomic Status, and SARS-CoV-2 Infection Among Pregnant Women in New York City. JAMA. 2020;324(4):390. doi:10.1001/jama.2020.11370

2. UCSF Health Atlas. Accessed October 7, 2020. https://healthatlas.ucsf.edu

3. Rudolph KE, Díaz I, Rosenblum M, Stuart EA. Estimating Population Treatment Effects From a Survey Subsample. Am J Epidemiol. Published online September 4, 2014:kwu197. doi:10.1093/aje/kwu197

4. Karp DG, Danh K, Espinoza NF, Seftel D, Robinson PV, Tsai C ting. A serological assay to detect SARS-CoV-2 antibodies in at-home collected finger-prick dried blood spots. Sci Rep.

2020;10(1):20188. doi:10.1038/s41598-020-76913-6 


\section{Adult-Child Survey}

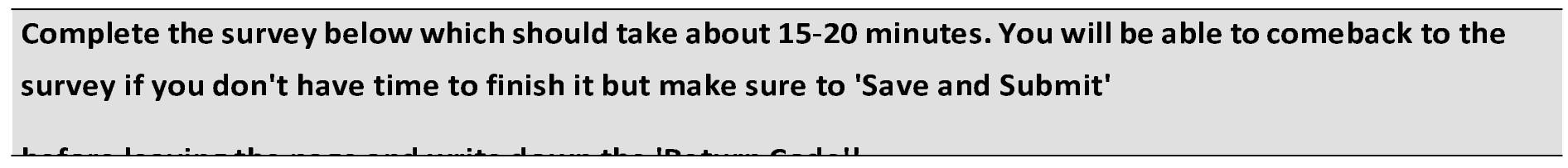

Date and Time of Main Adult or Child Survey

This is the survey for an Adult without a blood test!

This is the survey for the Adult testing kit!

You told us in the registration survey that multiple adults live in your household. The adult whose birthday is coming up next should take the survey and do the blood test using the testing kit. However, if that adult doesn't want to jointhe study, the adult with the next upcoming birthday should join the study and so on.

This is the survey for a Child without a blood test!

This is the survey for the Child testing kit!

You told us in the registration survey that multiple children live in the household. The child whose birthday is comingup next should take the survey and do the blood test using the testing kit.

However, if that child doesn't want to join the study, the child with the next upcoming birthday should join the studyand so on.

Only children ages 6 months to 17 years old can join the study.

You told us in the registration survey that multiple children live in the household. The child whose birthday is comingup next should take the survey.

However, if that child doesn't want to join the study, the child with the next upcoming birthday should join the studyand so on.

Only children ages 6 months to 17 years old can join $\stackrel{O}{\text { the study. }}$

Are you a parent or guardian answering this survey for 


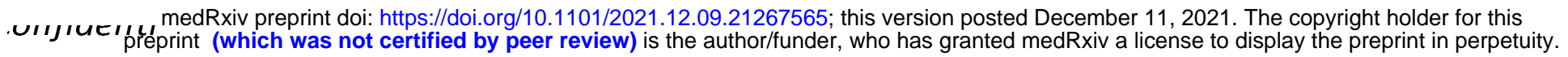
It is made available under a CC-BY-NC-ND 4.0 International license .

"You" in all the following questions are asking about the child. For example, "how old are you?" is asking "how old isthe child?".

How old are you?

(ye
ars
old
)

This is an ADULT survey. Adults must be 18 years or older.

This is a CHILD survey. Children must be between 6 months and 17 years old. 
ury ' 'preprint (which was not certified by peer review) is the author/funder, who has granted medRxiv a license to display the preprint in perpetuity. It is made available under a CC-BY-NC-ND 4.0 International license .

\begin{tabular}{ll}
\hline What is your sex (at birth)? & O Male \\
& O Female \\
& ODon't know \\
& Orefer not to answer \\
\hline How likely is it that you ever had coronavirus & O Very Likely \\
(COVID-19)? & OLikely \\
& OUnsure \\
& OUnlikel \\
& Oy Very Unlikely \\
\hline
\end{tabular}

The following questions are about the [baseline_arm_1][hh_tsize] members living in your household.

Only tell us about 10 out of the [baseline_arm_1] [hh_tsize] people in your household.

For children less than 6 months old, enter in age as 0.

What is the age of 2 nd person?

(years old)

$\begin{array}{ll}\text { What is the sex of the 2nd person (at birth)? } & \text { O Male } \\ \text { OFemale } & \text { ODon't know } \\ \text { OPrefer not to answer }\end{array}$

How likely is it this 2 nd person ever had coronavirus (COVID-19)?
Very Likely
Likely
Unsure
Unlikel
Oy Very Unlikely

What is the age of 3rd person?

(years old)

\begin{tabular}{ll}
\hline What is the sex of the 3rd person (at birth)? & O Male \\
& OFemale \\
& ODon'tknow \\
& OPrefernottoanswer
\end{tabular}

\begin{tabular}{ll}
\hline How likely is it this 3rd person ever had coronavirus & OVery Likely \\
(COVID-19)? & OLikely \\
& OUnsure \\
& Oy Unlikel \\
& Very Unlikely
\end{tabular}

What is the age of 4 th person?

(years old)

What is the sex of the 4th person (at birth)?

Male
Female
Don't know 
ur muedRxiv preprint doi: https://doi.org/10.1101/2021.12.09.21267565; this version posted December 11, 2021. The copyright holder for this ' 'preptint (which was not certified by peer review) is the author/funder, who has granted medRxiv a license to display the preprint in perpetuity. It is made available under a CC-BY-NC-ND 4.0 International license .

\begin{tabular}{ll}
\hline How likely is it this 4th person ever had coronavirus & O Very Likely \\
(COVID-19)? & OLikely \\
& OUnsure \\
& OUnlikel \\
& Oy \\
& Very Unlikely
\end{tabular}

What is the age of 5 th person?

(years old)

What is the sex of the 5th person (at birth)?
Male
Female
Don'tknow
Prefer not to answer

\begin{tabular}{ll}
\hline How likely is it this 5th person ever had coronavirus & O Very Likely \\
(COVID-19)? & OLikely \\
& OUnsure \\
& OUnlikel \\
& Oy Very Unlikely
\end{tabular}

What is the age of 6 th person?

(years old)

What is the sex of the 6th person (at birth)?
Oale
O Female
Don'tknow
Prefer not to answer

How likely is it this 6th person ever had coronavirus (COVID-19)?
Very Likely
Likely
Unsure
Unlikel
Oy
Very Unlikely

What is the age of 7 th person?

$$
\text { (years old) }
$$

What is the sex of the 7th person (at birth)?
Male
Female
Don'tknow
Prefer not to answer

$\begin{array}{ll}\text { How likely is it this 7th person ever had coronavirus } & \text { O Very Likely } \\ \text { (COVID-19)? } & \text { OLikely } \\ & \text { Onsure } \\ & \text { OUnlikel } \\ & \text { Oy } \\ & \text { Very Unlikely }\end{array}$

What is the age of 8 th person? 
ury ' 'preptint (which was not certified by peer review) is the author/funder, who has granted medRxiv a license to display the preprint in perpetuity. It is made available under a CC-BY-NC-ND 4.0 International license .

\begin{tabular}{ll}
\hline What is the sex of the 8th person (at birth)? & O Male \\
& OFemale \\
Don'tknow & Orefer not to answer \\
& \\
\hline How likely is it this 8th person ever had coronavirus & OVery Likely \\
(COVID-19)? & OLikely \\
& Onsure \\
& Oylikel \\
& Very Unlikely \\
\hline
\end{tabular}

What is the age of 9 th person?

$$
\text { (years old) }
$$

\begin{tabular}{ll}
\hline What is the sex of the 9th person (at birth)? & O Male \\
& OFemale \\
& ODon'tknow \\
& OPrefernottoanswer
\end{tabular}

\begin{tabular}{ll}
\hline How likely is it this 9th person ever had coronavirus & OVery Likely \\
(COVID-19)? & Likely \\
& Onsure \\
& Onlikel \\
& Oy \\
& Very Unlikely
\end{tabular}

What is the age of 10 th person?

$$
\text { (years old) }
$$

What is the sex of the 10th person (at birth)?
Male
Female
Don'tknow
Prefer not to answer

\begin{tabular}{ll}
\hline How likely is it this 10th person ever had coronavirus & OVery \\
Likely(COVID-19)? & Oikely \\
& Onsure \\
& Onnlikel \\
& Oy Very Unlikely
\end{tabular}

Of the [baseline_arm_1][hh_tsize] person(s) living in your household:

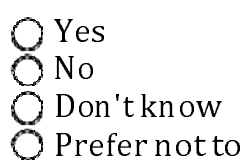

Has anyone ever been told by a healthcare provider answerthat they likely have coronavirus (COVID-19)?

How many were told they likely have coronavirus(COVID-19) by a healthcare provider?

$$
(\operatorname{person}(s))
$$

Now we have some additional questions about your household.

How many separate rooms (e.g. bedrooms, kitchens, unfinishedbasements.


ur medRxiv preprint doi: https://doi.org/10.1101/2021.12.09.21267565; this version posted December 11, 2021. The copyright holder for this 'preprint? (which was not certified by peer review) is the author/funder, who has granted medRxiv a license to display the preprint in perpetuity.

It is made available under a CC-BY-NC-ND 4.0 International license .

Page 32

$(\operatorname{room}(\mathrm{s}))$ 
med priv preprint doi: https://doi.org/10.1101/2021.12.09.21267565; this version posted December 11, 2021. The copyright holder for this ' 'preptint (which was not certified by peer review) is the author/funder, who has granted medRxiv a license to display the preprint in perpetuity.

It is made available under a CC-BY-NC-ND 4.0 International license .

Since April 1, 2020:

Yes
No

Have any of the adults in your household had to go to work in person (outside of the home)?

What types of jobs have members in your householdworked in person (outside of the home)?

Check all that apply.
Healthcare/first responder

Cashier or front-line worker at essential

$\square$ businessConstruction/landscaping

$\square$ Education or childcare

$\square$ Transportation driver or app-based driver (e.g. Uber, Lyft, food delivery)

$\square$ Factory worker

Agriculture/farm worker

Worker in meat processing facility

Worker in group setting (long-term care facility,nursing home, assisted living facility, correctional facility, homeless shelter)

$\square$ Worker in hair/nail salon or other personal careservices

$\square$ Other job where in-person (outside of the home)work was required

Since April 1,2020:

Yes

Has anyone in your household attended school

No orschool-related activities in person?

What types of school or school-related activities haveyour household members attended in person?

Check all that apply.

\author{
Daycare or preschool \\ Other childcare/after-school \\ $\square$ careElementary school \\ $\square$ Middle \\ schoolHigh \\ $\square$ school \\ Participating in social or education programs (for \\ example sports, arts) \\ $\square$ College/university (undergraduate or graduate \\ school) \\ $\square$ Vocational school or community college
}

In the past 12 months:

What was your total household income from all sources $\$ 49,999$ (before taxes)?

$\$ 74,999$
Has your household income changed due to the COVID-19 pandemic?

decreased

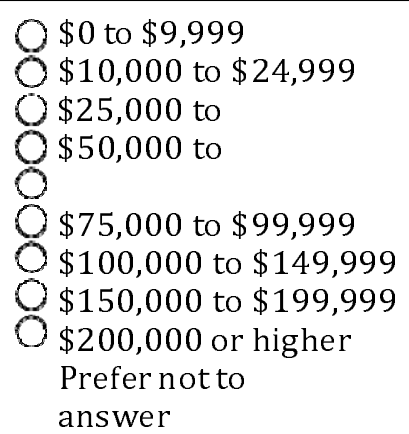

Yes, it increased

Yes, it

O

No

$\bigcirc$ Prefer not to answer

Now we have questions just for you. 
ur medRxiv preprint doi: https://doi.org/10.1101/2021.12.09.21267565; this version posted December 11, 2021. The copyright holder for this ur 'preptinh (which was not certified by peer review) is the author/funder, who has granted medRxiv a license to display the preprint in perpetuity.

It is made available under a CC-BY-NC-ND 4.0 International license .

Are you of Hispanic, Latino, or Spanish origin?Check all that apply.
No, not Hispanic, Latino, or Spanish origin Yes, Mexican, Mexican American, $\square$ ChicanoYes, Puerto Rican

$\square$ Yes, Cuban

$\square$ Yes, other Hispanic Latino, or Spanish originPrefer not to answer

Specify other Hispanic, Latino, or Spanish origin

What is your race?

Check all that

apply.
American Indian or Alaska

$\square$ NativeBlack or African

American

White

Asian Indian

$\square$ Chinese

Filipino

$\square$ Japanese

$\square$ Korean

$\square$ Vietnamese

$\square$ Other Asian (specify)

$\square$ Native Hawaiian

$\square$ Guamanian or Chamorro

$\square$ Samoan

$\square$ Other Pacific Islander (specify)

$\square$ Other race (specify)

Prefer not to answer

Specify other race

What is your current gender identity?

Male

Femal

Oe

Trans male/Transman

Trans

female/Transwoman

$\bigcirc$ Genderqueer or non-

$\bigcirc$ binaryldentity not listed

Prefer not to answer

What is your sexual orientation?

Heterosexual or straight

Gay, lesbian, or same gender

O lovingBisexual

Questioning, unsure, or don't

knowOrientation not listed

Prefer not to answer

What is the highest degree or level of school you have completed? $\bigcirc$ Less than high school

High school/General Educational Development

$\mathrm{O}$ (GED)Some college

Associate's degree (for example: AA,

O AS)Bachelor's degree (for example: BA,

BS) Master's degree or higher

Prefernotto answer

Do you currently have health insurance?

OYes

ONo 

ur 'prepeint
which was not certified by peer review) is the author/funder, who has granted medRxiv a license to display the preprint in perpetuity.

It is made available under a CC-BY-NC-ND 4.0 International license .

What type(s) of health insurance do you currentlyhave? Check all that apply.
Private health insurance that I get from my employer

$\square$ Private health insurance that I or a family memberbuys from an insurance company

$\square$ Private health insurance that I get through Covered California

$\square$ Medi-Cal (sometimes called Medicaid)

$\square$ Medicare

$\square$ Military insurance such as Tricare

$\square$ The Veterans Administration (VA)

$\square$ Alaska Native, Indian Health Service, or Tribal Health Services

$\square$ Other

Don'tknow
Have you lost or had your health care coverage reduced due to the COVID-19 pandemic?
OYes

No

Not applicable, I did not have health insurance coverage before the COVID19 pandemic

O Prefer not to answer
Are you currently a student?

How are you atten ding classes?
Yes, full-time student

Yes, part-time

OstudentNo
Which best describes your current work status?

In person only

By distance learning or virtually only

$\mathrm{A}$ mix of in-person and by distance learning or virtually

\author{
$\bigcirc$ Employed for wages full- \\ time Employed for wages \\ part-timeSelf-employed \\ A homemaker \\ Retired \\ Out of work for 12 months or more \\ Out of work for less than 12 \\ monthsUnable to work (disabled) \\ Full-time student \\ Prefernot to \\ answer
}

The next questions are about your most recent job.

What kind of work do you do?

For example, registered nurse, janitor, cashier, auto mechanic.

What kind of business or industry do you work in?

For example, hospital, elementary school, clothing manufacturing, or restaurant.

Do you mainly work from home?

ONes 

ur 'prepeint
which was not certified by peer review) is the author/funder, who has granted medRxiv a license to display the preprint in perpetuity.

It is made available under a CC-BY-NC-ND 4.0 International license .

Are you currently working in any of the following job types in person (outside of the home)?

If more than one, please select your main job.

\author{
Healthcare/first responder \\ Cashier or front-line worker at essential \\ businessConstruction/landscaping \\ Education or childcare \\ Transportation driver or app-based driver (e.g. \\ Uber, Lyft, food delivery) \\ Factory worker \\ Agriculture/farm worker \\ Worker in meat processing facility \\ $\bigcirc$ Worker in group setting (long-term care \\ facility, nursing home, assisted living facility, \\ correctional facility, homeless shelter) \\ Worker in hair/nail salon or other personal \\ careservices \\ Other job where in-person (outside of the \\ home)work is required
}

The next questions ask you about your activities and interactions with others during the COVID-19 pandemic.

"You" in all the following questions are asking about the child. For example, "Have you been in close contact?" isasking "Has the child been in close contact?".

In the past 6 months:

Have you been in close contact with someone who has been diagnosed with coronavirus (COVID-19), around the answertime of their diagnosis?

Close contact is being within 6 feet of a person forat least 15 minutes.

In the last month:

How often have you visited grocery stores, pharmacies, weekor other essential service providers?
Y Yes
No
Don't know
$\bigcirc$ Prefer not to
Several times a day
Once a day
Several times a
Once a week
Once every two weeks
Once every three weeks
Monthly or less often
Never

In the last month:

Have you visited (for at least 15 minutes) any of thefollowing services or venues outdoors?

Check all that apply.
Dining at a restaurant (not take-out only)

Bars, breweries, distilleries (where no meal isprovided)

$\square$ Wineries

$\square$ Gyms and fitness centers

$\square$ Hair or nail salon or other personal care $\square$ servicesShopping centers or other non-

$\square$ essential retail Hotels and lodging

$\square$ Places of

$\square$ worshipMovie

$\square$ theaters

$\square$ Playgrounds and recreational facilities

$\square$ Museums, zoos, aquariums Other entertainment (family entertainment, cardrooms)

None of the above 
med pxiv preprint doi: https://doi.org/10.1101/2021.12.09.21267565; this version posted December 11, 2021. The copyright holder for this I' 'preperint (which was not certified by peer review) is the author/funder, who has granted medRxiv a license to display the preprint in perpetuity.

It is made available under a CC-BY-NC-ND 4.0 International license .

In the last month:

Have you visited (for at least 15 minutes) any of thefollowing services or venues indoors?

Check all that apply.
Dining at a restaurant (not take-out only)

$\square$ Bars, breweries, distilleries (where no meal isprovided)

$\square$ Wineries

$\square$ Gyms and fitness centers

$\square$ Hair or nail salon or other pers onal care

$\square$ servicesShopping centers or other non-

$\square$ essential retail Hotels and lodging

$\square$ Places of

$\square$ worshipMovie

$\square$ theaters

$\square$ Playgrounds and recreational facilities

$\square$ Museums, zoos, aquariums Other entertainment (family entertainment, cardrooms)

None of the above
In the last month:

Have you been to a social gathering with the followinggroup sizes?

Don't count people who live in your household. Check all that apply.

Were these social gatherings indoors or outdoors?
1 to 10

11 to 20

$\square 21$ to 50

$\square 51$ to 100

$\square$ Greater than 100

$\square$ None of the above

$\square$ Don't know

$\square$ Prefer not to answer

Indoor only

Outdoor only

$\bigcirc$ Both indoors and outdoors
How often have you attended any of these social gatherings?
Several times a day

Once a day

Several times a

weekOnce a week

Once every two weeks

Once every three weeks

Monthly or less often
How often do you wear a face mask at these social gatherings?
Always (100\%)
Often (70-99\%)
O Sometimes (31-69\%)
Rarely $(1-30 \%)$
Never $(0 \%)$

In the last month:

Have you gathered with friends or family either at outdoorsyour home or at theirs?

Yes, indoors only

Yes, outdoors only

Yes, both indoors and

ONo

Only count gatherings that included people who do not live in your household.

How often do you wear a face mask at these home gatherings?

\author{
Always (100\%) \\ Often (70-99\%) \\ Sometimes (31-69\%) \\ O Rarely (1-30\%) \\ Never (0\%)
}



ur 'prepeint
which was not certified by peer review) is the author/funder, who has granted medRxiv a license to display the preprint in perpetuity.

It is made available under a CC-BY-NC-ND 4.0 International license .

How often are you trying to keep at least 6 feet between you and other people you don't live with to avoid spreading the virus?

$69 \%$ )

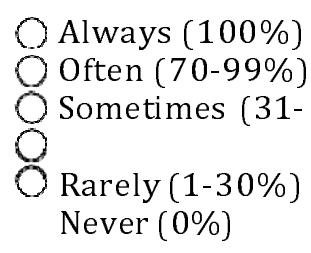

Always (100\%)

Often $(70-99 \%)$

Sometimes (31-

O

Rarely (1-30\%)

Never (0\%)

How often do you wear a face mask when leaving your $(100 \%)$ house?

99\%)

\author{
Always \\ Often (70- \\ Sometimes (31-69\%) \\ Rarely (1-30\%) \\ Never $(0 \%)$
}

O

The next questions will ask about COVID-19 testing and any symptoms you may have had.

"You" in all the following questions are asking about the child. For exa mple, "Have you experienced?" is asking "Hasthe child experienced?".

\begin{tabular}{ll}
\hline Have you experienced any of the following & $\square$ Fever \\
symptomssince February 1, 2020? & $\square$ Chills \\
$\square$ & Cough \\
$\square$ & Sertness of breath or difficulty breathing \\
$\square$ Muscle or body & $\square$ achesFa tigue \\
$\square$ & New loss of taste or smell \\
$\square$ & Sore throat \\
$\square$ & Runny or stuffy nose \\
$\square$ & Nausea or vomiting \\
$\square$ & Diarrhea \\
$\square$ & None of the above
\end{tabular}

When did these symptoms start?

Less than 2 weeks

Q ago2-4 weeks ago

More than 4 weeks

agoDon't know

Prefer not to answer

Which month?

January 2020

February 2020

March 2020

April 2020

May 2020

June 2020

July 2020

August 2020

September 2020

October 2020

November 2020

December 2020

January 2021

February 2021

How bad were your worst symptoms?

O I was mildly sick- I could go about my daily tasksnormally

O I was moderately sick- I didn't want to do choresbut I didn't feel so sick I had to stay in bed all day 


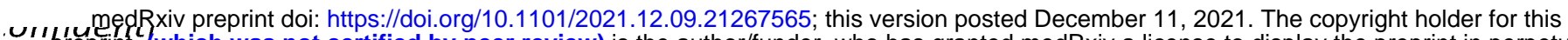
" preppint ( which was not certified by peer review) is the author/funder, who has granted medRxiv a license to display the preprint in perpetuity. It is made available under a CC-BY-NC-ND4.0 Was so sick-I had to be hospitalized

Page 39 
ury medRxiv preprint doi: https://doi.org/10.1101/2021.12.09.21267565; this version posted December 11 , 2021. The copyright holder for this I' preppint (which was not certified by peer review) is the author/funder, who has granted medRxiv a license to display the preprint in perpetuity.

It is made available under a CC-BY-NC-ND 4.0 International license .

Did you go to urgent care, the emergency room, have a telehealth (online) visit, or see a medical provider (e.g., doctor, nurse, physician assistant) for these symptoms?

Yes
No
Don't know
Prefer not to answer

Only going to a COVID-19 testing site does not count.

Has a healthcare provider ever told you that you likely have coronavirus (COVID-19)?
Y Yes
No
Don't know
Prefer not to answer

When did the provider tell you that you had coronavirus (COVID-19)?
Less than 2 weeks ago

2-4 weeks ago

More than 4 weeks

agoDon'tknow

Prefer not to answer

Which month?

OJanuary 2020

February 2020

March 2020

April 2020

May 2020

June 2020

July 2020

August 2020

September 2020

October 2020

November 2020

December 2020

January 2021

February 2021

Have you ever been tested for coronavirus (COVID-19)

with a nasal swab, oral swab, or saliva test?
Y Yes
No
Don't know
Prefer not to answer

Have you ever tested positive for coronavirus (COVID-19) with a nasal swab, oral swab, or saliva test?
Y Yes
No
Don't know
$\bigcirc$ Prefer not to answer

When did you test positive for coronavirus (COVID-19) agowith a nasal swab, oral swab, or saliva test?

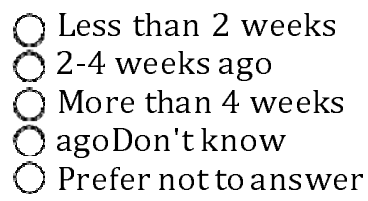


urumedRxiv preprint doi: https://doi.org/10.1101/2021.12.09.21267565; this version posted December 11 , 2021. The copyright holder for this I' 'preperint (which was not certified by peer review) is the author/funder, who has granted medRxiv a license to display the preprint in perpetuity.

It is made available under a CC-BY-NC-ND 4.0 International license .

Which month?
O January 2020
February 2020
March 2020
April 2020
May 2020
June 2020
July 2020
August 2020
September 2020
October 2020
November 2020
December 2020
January 2021
February 2021

What was the reason you chose to get tested?Check all that apply.
I had symptoms of COVID-19

Someone I know had symptoms or was diagnosed withCOVID-19

$\square$ My job offered or required me to get tested oncefor COVID-19

$\square$ My job offered or required me to get tested on a regular basis for COVID-19

$\square$ I chose to get tested on a regular basis for personal reasons (e.g. for travel or to attend social gatherings)

$\square$ Testing was required for a healthcare visit or medical procedure

I was worried about COVID-19

Other

Specify other

At any time did you want to get a coronavirus (COVID-19) test (nasal swab, oral swab, or saliva test), but you were unable to get tested?
$\bigcirc$ Yes
No
Don't know
$\bigcirc$ Prefer not to answer

Have you ever had an antibody (blood) test for COVID-19?

Yes
No
ODon't know
Prefernot to answer

What was your result?

Positive- I had antibodies

Use the most recent, if more than one.

Negative- antibodies were not detected

Indeterminate- the test did not

$O$ workI don't remember

O never got my result

When did you test positive for an antibody (blood) agotest for COVID-19?

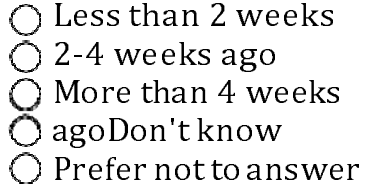


urumedRxiv preprint doi: https://doi.org/10.1101/2021.12.09.21267565; this version posted December 11, 2021. The copyright holder for this ' 'préprint (which was not certified by peer review) is the author/funder, who has granted medRxiv a license to display the preprint in perpetuity.

It is made available under a CC-BY-NC-ND 4.0 International license .

Which month?
O January 2020
February 2020
March 2020
April 2020
May 2020
June 2020
July 2020
August 2020
September 2020
October 2020
November 2020
December 2020
January 2021
February 2021

Have you ever been hospitalized for COVID-19?

Yes
No
Don't know
$\bigcirc$ Prefer not to answer

The next questions are about your general health.

"You" in all the following questions are asking about the child. For example, "How tall are you?" is asking "How tall is the child?".

How tall are you withoutshoes?

Centimeters $(\mathrm{cm})$

$\bigcirc$ feet (ft) and inches (in)

Height (feet)

(ft)

Height (inches)

(in)

Height (centimeter)

$(\mathrm{cm})$

You entered in your height as [height_ft] ft [height_in] in.

How much do you weigh?

Okilograms (kg)

Opounds (lb)

Weight (kilograms)

$(\mathrm{kg})$

Weight (pounds)

(lb)

In the last 12 months:

$\bigcirc$ Yes

Have you had a flu vaccine?

ODon'tknow 

ur preppint
mhich was not certified by peer review) is the author/funder, who has granted medRxiv a license to display the preprint in perpetuity.

It is made available under a CC-BY-NC-ND 4.0 International license .

Which year?

O 2020

O2021

Do you currently smoke every day, some days, or not at all?

days

Smoking includes cigarettes, marijuana, e-cigarettes, vaping, etc.

\author{
Every day \\ Some \\ $\mathrm{O}$ \\ Notat all \\ Don'tknow \\ Prefer not to answer
}

Do you currently have any of the following medicalissues?

Check all that apply.

Active Cancer $\square$ Chronic Kidney Disease

$\square$ Chronic Lung diseases (asthma, Chronic ObstructivePulmonary Disease (COPD), pulmonary fibrosis, cystic fibrosis]

$\square$ Former smoker

$\square$ Heart conditions like heart failure, coronaryartery disease,

$\square$ cardiomyopathies Hypertension or high

$\square$ blood pressure

$\square$ Cerebrovascular disease (e.g. history of strokes)

$\square$ Chronic Liver Disease Immunocompromised state (weakened immune system)from solid organ or bone marrow transplant, immune deficiencies, HIV, taking steroids or other immune weakening medicines

$\square$ Neurologic or neuromuscular disorders (e.g. dementia, Parkinson's disease)

$\square$ Sickle Cell Disease

$\square$ Thalassemia (a blood

$\square$ disorder) Diabetes (type 1

$\square$ and 2)

None of the above
Are you currently pregnant?

Do you need help with any activities like walking outside, going up and down stairs, getting dressed, or bathing?
Yes
No
Don't know
Prefernot to
OanswerNot applicable

Have you gotten a coronavirus vaccine?
Yes
(O)
Don't know
Prefernotto answer
$\bigcirc$ Yes
No
Don'tknow
Prefer not to answer

Which vaccine did you get?

Pfizer-

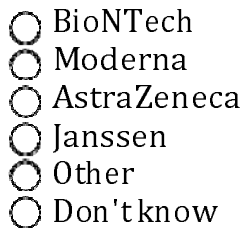


urmegdRxiv preprint doi: https://doi.org/10.1101/2021.12.09.21267565; this version posted December 11, 2021. The copyright holder for this

preprint (which was not certified by peer review) is the author/funder, who has granted medRxiv a license to display the preprint in perpetuity. When did you get your first dose?

Page 44

Is made available under a CC-BY-NG-ND 4.0 Internationallieense. 
med priv preprint doi: https://doi.org/10.1101/2021.12.09.21267565; this version posted December 11, 2021. The copyright holder for this ' 'preptint (which was not certified by peer review) is the author/funder, who has granted medRxiv a license to display the preprint in perpetuity.

It is made available under a CC-BY-NC-ND 4.0 International license .

When did you get your second dose?

\begin{tabular}{ll}
\hline Did you get the coronavirus vaccine as part of a & OYes \\
research study or clinical trial? & O No \\
& O Don't know \\
& O Prefernottoanswer
\end{tabular}

If a vaccine for COVID-19 was offered to you, how likely is it you would take it?
Very Likely
Likely
Onsure
Unlikel
Oy
Very Unlikely

The next questions are about the economic impacts of the COVID-19 pandemic on you.

\section{Since April 2020:}

Were you ever laid off, furloughed from your job, or 19 had your work hours reduced?

In the next three months:

How likely is it that you will run out of money because of the pandemic?
OYes
No
Not applicable, I was not working prior to COVID-
In the past seven days:
Were you worried about running out of food?

Yes
No
Don't know
Prefer notto answer

The last few questions are about your attendance in school and other activities.

"You" in all the following questions are asking about the child. For example, "Are you a student?" is asking "Is thechild a student?".

\footnotetext{
Are you a student in one of the following settings (either in person or by distance learning)? Check allthat apply.
}

$\square$ Daycare or preschool
$\square$ Other childcare/after-school
$\square$ careElementary school
$\square$ Middle
$\square$ schoolHigh
$\square$ school Other
$\square$ None of the above




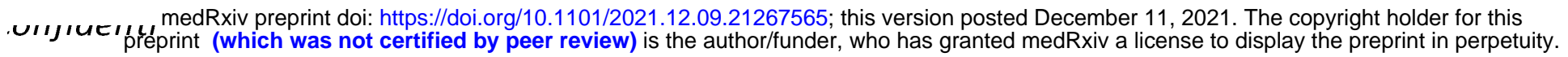

It is made available under a CC-BY-NC-ND 4.0 International license .

Page 46

Specify other

In the last 4 months: How have you been going to classes?

0

In person only

virtually only

By distance learning or

A mix of in-person and

by distance learning or

virtually

In the last 4 months: Have you attended any in-person

sports, arts)?
Yessocial events or other education progra Don't know

Prefer not to answer 